\title{
PEMBELAJARAN AKUNTANSI SEBAGAI MEDIA PENANAMAN KARAKTER ANTI KORUPSI
}

\section{ACCOUNTING AS ANTI CORRUPTION CHARACTER MEDIA}

Oleh :

\author{
Siswanto \\ Universitas Negeri Yogyakarta \\ siswanto@uny.ac.id
}

\begin{abstract}
Abstrak
Penelitian ini bertujuan untuk mengetahui: (1) Bagaimana persiapan pembelajaran akuntasi sebagai media penanaman karakter akti korupsi; (2) Bagaimana pelaksanaan pembelajaran akuntansi; (3) Bagimana penilaian pembelajaran akuntansi ; (4) Bagaimana kualitas pembelajaran akuantansi sebagai media penanaman karakter anti korupsi; (5) Nilai - nilai karakter yang muncul dalam pembelajaran Akuntansi di Sekolah Menengah Kejuruan (SMK) di Daerah Istimewa Yogyakarta. Jenis Penelitian dikategorikan pada jenis diskriptif kuantitatif. Populasi penelitian adalah Guru Akuntansi berjumlah 279, dengan populasi penelitian 165 guru yang diambil dengan proporsional purposive sampling. Instrumen penelitian berupa angket/kuesioner dan lembar observasi. Teknis analaisis data yang digunakan dengan Analisis diskriptif kuantitatif. Hasil penelitian menunjukkan (1) Persiapan Pembelajaran Akuntansi pada kategori sangat baik sebagai media penanaman karakter anti korupsi; (2) Pelaksanaan Pembelajaran Akuntansi pada kategori sangat baik sebagai media penanaman karakter anti korupsi; (3) Penilaian Pembelajaran Akuntansi pada kategori sangat baik sebagai media penanaman karakter anti korupsi; (4) Kualitas Pembelajaran Akuntansi pada kategori baik sebagai media penanaman karakter anti korupsi ; (5) Nilai-nilai karakter anti korupsi yanag muncul dalam pembelajaran : Kejujuran, kemandirian, keberanian, Kerjakeras dan Disiplin seluruhnya pada kategori Baik.
\end{abstract}

Kata Kunci : Karakter, Anti Korupsi, Pembelajaran Akuntansi

\section{Abstract}

This study aims to find out: (1) How to prepare for accounting learning as a medium for planting Anti-Corruption characters; (2) How is the implementation of accounting learning; (3) How is the accounting learning assessment; (4) How is the quality of aquantance learning as a medium for planting Anti-Corruption characters; (5) Character values that arise in learning Accounting in Vocational High Schools (SMK) in the Special Region of Yogyakarta. Research types are categorized as quantitative descriptive types. The study population was 279 Accounting Teachers, with a research population of 165 teachers taken with proportional purposive sampling. Research instruments in the form of questionnaires / questionnaires and observation sheets. Technical analysis of data used with quantitative descriptive analysis. The results showed (1) Accounting Learning Preparation in the excellent category as a medium for planting anti-corruption character; (2) Implementation of Accounting Learning in the excellent category as a medium for planting anti-corruption character; (3) Assessment of Accounting Learning in the excellent category as a medium for planting anti-corruption character; (4) Quality of Accounting Learning in both categories as a medium for planting anti-corruption characters; (5) The values of anti-corruption characters that appear in learning: Honesty, independence, courage, hard work and discipline are all in the Good category.

Keywords: Character, Anti-Corruption, Accounting Learning 


\section{PENDAHULUAN}

Pemberitaan terkait tindak pidana korupsi hampir setiap hari kita temukan di media massa dan media elektronik dengan berbagai modus dan cara yang dilakukan oleh pelaku korupsi yang merugikan keuangan negara. Meningkatnya tindakan korupsi dapat kita ketahui dari informasi tentang penanganan perkara yang dilakukan oleh KPK dari tahun 2004 - 2018 : penyelidikan 1.135 perkara, penyidikan 887 perkara, penuntutan 719 perkara, inkracht 578 perkara, dan eksekusi 610 perkara (www.acch.kpk.go.id ). Data jenis perkara korupsi adalah kasus penyuapan, pengadaan barang dan jasa, dan penyalahgunaan anggaran.

Upaya pencegahan tindakan korupsi tidak hanya dilakukan pada satu generasi saja, melaikan dua atau tiga generasi selanjutnya. Penanaman sikap anti korupsi di setiap jenjang pendidikan dapat di jadikan sebagai tindakan awal untuk menghasilkan generasi yang memahami betul akan bahaya korupsi dalam berbagai aktivitas. Pendidikan nilai-nilai anti korupsi dapat dilaksanakan pada peserta didik pada sekolah dasar hingga pendidikan tinggi. Fungsi Pendidikan dalam penanggulangan aktivitas yang mengarah pada tidakan korupsi sangat bagus di integrasikan dalam domain afektif (sikap), kognitif (pengetahuan) dan psikomotor (keterampilan).

Akuntansi merupakan proses untuk mendapatkan informasi untuk mengetahui aktivitas ekonomis perusahaan untuk para pemakai informasi. Warren (2015) mengungkapkan " Accounting is an information system that provises report to stake holder abaout the economic avtivities and condition of business ". Definisi lain Akuntasi adalah setiap tahapan pengambilan keputusan, keberadaan informasi mempuyai peranan penting mulai dari proses pengidentifikasian persoalan mencari alternatif pemecahan masalah dan monitor pelaksanaan keputusan yang diterapkan (Akhyar Adnan, 2016). Akuntansi sebagai bidang ilmu yang mempelajari seluk beluk pencatatan sampai dengan pelaporan keuangan dapat digunakan untuk sarana dalam melakukan pencegahan awal tindakan yang mengarah pada korupsi dengan memasukkan berbagai nilai-nilai untuk melakukan penolakan pada korupsi. Hal ini dapat dilakukan dengan memasukkan berbagai nilai dalam setiap aktivitas belajar peserta didik sebagai sarana pencegahan serta gerakan penanggulangan timbulnya tindakan yang mengarah pada aktivitas yang korup pada generasi bangsa. Kegiatan pembelajaran akuntansi merupakan sarana yang efektif untuk menumbuhkan nilai karakter anti korupsi, karena dalam proses pembelajaran terjadi proses internalisasi yang melibatkan berbagai unsur dan potensi siswa/mahasiswa. Proses pembelajaran yang memiliki karakteristik terstruktur, terencana dan terukur merupakan kegiatan yang sangat tepat untuk menanamkan berbagai nilai dengan paramater yang terukur.

Undang-undang No. 20 tahun 2008 tentang Sistem Pendidikan Nasional dan Instruksi Presiden Republik Indonesia Nomor 1 Tahun 2010 tentang Percepatan Pelaksanaan Prioritas Pembangunan Nasional Tahun 2010 mengamatkan untuk memasukan nilai-nilai karakter dan budaya bangsa yang di integrasikan dalam metodologi, kurikulum serta metode pembelajaran yang dapat digunakan sebagai sarana/media untuk implementasi pendidikan karakter.

Pemerintah melalui Kementerian Pendidikan Nasional dan Komisi Pemberantasan Korupsi mulai dari tahun 2011 melakukan kesepakanan dalam kerjasama dalam usaha untuk menerapkan Pendidikan Antikorupsi dalam kurikulum prasekolah sampai jenjang Perguruan Tinggi. Integrasi nilai karakter sebagai Pendidikan anti korupsi di maksudkan tidak hanya menjadi perubahan konseptual yang mungkin susah untuk di pahami dan dilaksanakan. Sesuai dengan program tersebut pendidikan karakter yang dilakukan diyakini dapat di sikronkan untuk melaksanakan pendidikan anti korupsi sebagai bagian kegiatan pengembangan nilai-nilai moralitas peserta didik. 
Pembelajaran merupakan transformasi dari seorang pengajar kepada peserta didik dengan mengunakan berbagai media yang digunakan dan berbagai kreasi pengajar dalam pembelajaran, pendekatan pembelajaran adalah bagaimana kelas dikelola. Menurut Worthen (2012): In order to learn as teacher intendented, student had to use resourcesfrom various times scale. The curriculum drew on social historical patterns that take place over centuries and dedicate. Intellectual position havedeveloped historically in various tradition, and the curricukum in this classroom drew on exemplars from various times and place.

Dari sudut pemakai akuntansi dapat didefinisikan sebagai "suatu ilmu yang menyediakan informasi yang diperlukan untuk melaksanakan kegiatan secara efisien dan mengevaluasi kegiatan-kegiatan suatu organisasi", sedang ditinjau dari sudut kegiatannya definisi akuntansi yaitu "Proses pencatatan, pengologan, peringkasan, pelaporan dan penganalisaan data keuangan suatu organisasi" (Warsono, 2013). Definisi akuntansi pendidikan adalah " salah satu dari bidang-bidang akuntansi yang berhubungan dengan kegiatan pengembangan dan penyebaran pendidikan".

Sebagai ilmu, definisi akuntansi menurut Nafarin (2015) "akuntansi adalah suatu disiplin ilmu yang mempelajari mekanisme, sistem dan prosedur dalam pencatatan, mengelompokkan, mengikhtisarkan dan melakukan intepretasi atas transaksi keuangan yang terjadi data suatu organisasi dan dinyatakan dalam suatu nilai uang". Hal ini sesuai pendapat dan dari Warren (2015) Accounting information composed principally of financial data about busines transaction, expressed in to of money.

Akuntansi sebagai proses (Nafarin, 2015) adalah "proses kegiatan yang mengenai transaksi keuangan suatu organisasi dalam melakukan pencatatan, penggolongan, pengikhtisaran, pemeriksaan, penafsiran dan penggangaran sehingga berguna bagi pihak yang berkepentingan dalam mengambil keputusan untuk menentukan langkah pada waktu yang akan datang. Mendefinisikan akuntansi sebagai kumpulan dan proses (analisis, pengukuran dan perekaman) dari data keuangan suatu organisasi dan pelaporan informasi bagi para pembuat keputusan. Akuntansi didefinisikan sebagai seni merekam dan merangkum transaksi bisnis dan pengaruhnya pada perusahaan bisnis. Hal tersebut didukug pendapat kieso, weygant, dan kimmel (2014) "Accounting is information system that identifies record and communicaticates the economic even of an organization to interest user".

Pembelajaran Akuntansi hendaknnya dilakukan latihan langsungdan bersifat individual. Hal ini dimaksudkan untuk membiasakan cara kerja dan beifikir mandiri. Sikap hidup yang produktif dan mandiri dibentuk dengan penerapan metode latihan untuk setiap materi pembeiajaran yang diberikan. Latihan yang diberikan hendaknya bukan latihan yang sifat kelompok sebab cara kerja berkelompok untuk pembelajaran akuntansi menjadi saling ketergantungan dan tidak akan terjadi pemahaman yang menyeluruh akan materi yang diberikan. Kegiatan latihan yang diberikan hendaknnya membuat siswa mendapatkan pengalaman belajar sendiri, mencoba sendiri dan mengerjakan sendiri tentang apa yang hendak dipelajari. Kegiatan ini lebih banyak melatih kemammpuan psikomotorik disamping juga membutuhkan kernampuan kognitif dan afektif. Proses belajar mengajar Akuntansi terdiri dari dua kegiatan utama yang saling berinteraksi bersama secara langsung, pertama kegiatan belajar dan kedua kegiatan mengajar, sebisa mungkin pembelajaran mengedepankan demokratisasi, sehingga proses pembelajaran dapat bejalan tiga arah antara pengajar dengan siswa dan siswa dengan siswa, sehingga siswa memiliki kesempatan untuk menyapaikan berbagai pendapat dan ide yang mereka miliki.

Pendidikan anti korupsi merupakan program yang diharapkan dapat membangun menumbuhkan kompetensi siswa akan akibat yang ditimbulkan dari tindakan korupsi. Salah satu tujuan Pendidikan anti korupsi adalah memberikan pemahaman tentang berbagai kegiatan yang berpotensi korupsi dengan kriteria : apa penyebab dari kegiatan tersebut dan akibat yang 
ditimbulkannya, serta menumbuhkan penilaian ketidak setujuan pada aktivitas yang mengarah pada tindakan menyimpang/korupsi tersebut. Selanjutnya dapat memilih dan melakukan aktivitas untuk melawan korupsi serta berperan aktif dalam mewujudkan nilai-nilai dan kapasitas untuk menentang korupsi dikalangan generasi muda. Siswa diharapkan mampu untuk menganalisis nilai - nilai yang berkontribusi terhadap terjadinya korupsi serta nilai-nilai yang menolak atau tidak setuju dengan tindakan korupsi. Oleh sebab itu pendidikan anti korupsi pada dasarnya adalah penanaman dan penguatan nilai-nilai dasar yang diharapkan mampu membentuk sikap anti korupsi pada diri siswa.

Sebagai gambaran Ministry of Education Lithuania yang dikutip Maria Montessori memberikan gambaran bahwa negara Lithuania sejak 2005 telah menerapkan pendidikan anti korupsi di negaranya, tujuan penanaman nilai anti korupsi adalah untuk menumbuhkan pengetahuan kepada peserta didik bagaimana mengidentifikasi bagaimana tindakan korupsi dan aktivitas lainnya, memberikan pengetahuan yang dapat diterima dan di pahami dengan mudah mengapa aktivitas yang mengarah korupsi dikategorikan sebagai suatu tindakan yang tidak bermoral, serta memberikan alternatif cara yang dapat ditempuh dalam mencegah terjadinya tindakan tersebut.

Menurut Dharma (2013) tujuan pendidikan anti korupsi adalah : (1) pembentukan pengetahuan dan pemahaman mengenai bentuk korupsi dan aspek-aspeknya; (2) pengubahan persepsi dan sikap terhadap korupsi; dan (3) pembentukan keterampilan dan kecakapan baru yang ditujukan untuk melawan korupsi.

Pendapat di atas dapat dilihat bahwa pendidikan anti korupsi selain mempunyai sasaran utama sebagai pendidikan nilai tetapi tetap meliputi enam tahap pendidikan sebagaimana dikemukakan oleh Bloom pada ranah kognitif terdiri dari enam level: remembering (mengingat), understanding (memahami), applying (menerapkan), analyzing (menganalisis, mengurai), evaluating (menilai) dan creating (mencipta).yaitu pengembangan ranah kognitif, afektif dan psikomotor siswa.

KPK sebagai lembaga yang terdepan dalam pemberantasan korupsi telah mengembangkan nilai-nilai dasar yang diharapkan dapat di integrasikan melalui pelaksanaan pendidikan yaitu nilai hidup sederhana, kerja keras, kejujuran, tanggung jawab adil, hemat, mandiri, berani dan disiplin,. Ke Sembilan nilai ini sebenarnya telah dimiliki dan ada di kehidupan kita semua dan dapat kita lihat dalam dasar implementasi dasar negara kita Pancasila, namun nilai tersebut terlihat mulai hilang dengan adanya terpaan Globalisasi yang akibatkan oleh modernisasi. Agar tujuan Pendidikan anti korupsi di lembaga pendidikan seyogyanya senantiasa menitik beratkan pada 1) Pengetahuan tentang Korusi, 2) Perubahan Sikap terhadap Korupsi (Modern Didactic Center, 2016) :

Pengertian "karakter" dilihat dari pendekatan filsafat dan hakikat pengetahuan memiliki arti sebagai pandangan umum dari psikologis atau nilai kejiwaan seseorang. Karakter memiliki hunungan yang erat antara nilai moralitas, akhlak atau watak, kepribadian, budi pekerti yang menjadi penciri atau pembeda seseorang dan yang lain atau dengan kata lain ciri khas yang dapat menjadikan seseorang mendapat keperpercayaan dalam kehidupan bermasyarakat.

Karakter merupakan cerminan dari kemampuan seseorang untuk menunjukkan pemahaman yang dimiliki dalam bersosialisasi dengan masyarakat dan lingkungannya. Dengan demikian di dalam karakter memiliki komponen sikap, moral serta perilaku yang dimiliki oleh seseorang. Merupakan kesulitan tersendiri apabila akan mengetahuan bagaimana seseorang mempunyai karakter tertentu, manakala belum menyaksikan moralitas, budi dan mengetahui kepribadian atau perilaku yang dimikili dari orang tersebut. Pakar Psikologi (Lickona, 2014) beberapa abad sebelumnnya, memiliki konsep perhatian yang serius tentang "karakter". hal ini terutama yang menfokuskan bagaimana upaya untuk memdapatkan definisi karakter untuk tujuan pembelajaran nilai -nilai kepribadian hingga pembentukan peserta didik yang memiliki 
karakter yang baik (good character). Oleh karena itu, karakter sebagai ukuran dari moralitas selalu menyatu dengan seberapa tingkat intelektual dan emosional seseorang. Menurut Cronbach \& Shavelson (2004)“character, however; is evidenced in the way a person handles dilemas, especially those where his wishes run counter to the interests of other persons". Dari paparan tersebut Cronbach tidak memunculkan secara jelas bagaimana kemampuan mengatasi permasalahan yang pelik sebagai salah satu ukuran seseorang untuk dapat memiliki kesuksesan dalam karir dan komunikasinya. Tetapi Cronbach memahami dan yakin bahwa segala keputusan yang menjadi pilihan sangat tergantung pada konsep, sikap, kebutuhan dan perasaan yang dimiliki oleh seseorang.

Selanjutnya Cronbach \& Shavelson dalam Catherine \& Petter Lehmann (2013) memberikan gambaran mengenai karakter sebagai berikut. "Character is not a cumulation of separate habits and ideas. Character is an aspect of the personality. Beliefs, feelings, and actions, are linked; to change character is to reorganize the personality. Tiny lessons on principles of good conduct will not be effective if they cannot be integrated with the person's sistem of beliefs about in self, about others, and about the good community".

Dari pemamaran tersebut, Cronbach \& Shavelson memberikan penekanan tentang nilai karakter sebagai satu bagian dari kepribadian yang terbentuk oleh kebiasaan dan gagasan yang terpadu dan saling menentukan satu dengan yang lain. Dalam pembentukan karakter memerlukan unsur-nsur keyakinan, perasaan, dan tindakan merupakan unsur-nsur yang tidak dapat dipisahkan sehingga untuk mengubah karakter berarti melakukan perubahan yang sangat fundamental pada Moralitas seseorang. Dengan kata lain, kondisi proses pembelajaran untuk membangun karakter peserta didik dapat menimbulkan dapak terhadap mutu sumberdaya manusia yang dihasilkan dalam pembelajaran tersebut. Unsur - unsur dalam pembelajaran yang baik tidak mungkin dilaksanakan dengan baik apabila tidak dapat disinkronkan dengan pemehaman dasar yang dimiliki, orang lain, dan masyarakat. Bagi Cronbach \& Shavelson dalam Catherine \& Petter Lehmann (2013) bentuk tindakan dan nilai yang baik adalah "in terms of the choices the individual makes when his actions affect the welfare of others: the person of good character generally tries to choose acts that promote the welfare of others as well as of himself ". memutuskan sesuatu pilihan merupakan hal yang biasa dialami oleh seseorang dalam kehidupan bermasyarakat. Pada saat seseorang harus menentukan antara dual ha atau lebih yang dianggap yang terbaik bagi masyakarat, maka kepribadian dan moralitas seseorang yang baik akan terlihat usaha yang dilakukan untuk mengarah pada kebaikan untuk semua. Sebaliknya, seseorang yang cenderungn memiliki sifat amoral akan senantiasa tidak memiliki pemahaman pada kebaikan sesama dan kepedulian terhadap akaibat dari aktivitas atau tindakan yang dilakukan. Orang yang belum memiliki pemahaman konsep yang memadai tentang karakter akan cenderung melakukan kegiatan yang tidak terpuji. Seorang yang memiliki nilai-nilai kebijaksanaa (expedient) adalah orang yang senantiasa melakukan kendali (be cotrolled) setiap aktivitas yang dilakukan yang berdampak pada orang lain. Orang yang bijaksana dan berkarakter sangan memperhatikan setiap reaksi yang di timbulkan yang timbul dari kegiatan yang dia lakukan pada orang lain.

Karakter terdiri dari tiga unsur yang saling terkait yakni moral feeling, moral knowing, dan moral behavior, hal ini menurut Lickona (2012) . Oleh karena itu, kepribadian seseorang memiliki tiga bagian utama, yaitu memiliki pengetahuan pada hal yang baik, memiliki keinginan melaksanakan hal yang baik, dan senantiasa berusaha melakukan hal yang baik sehingga ketiga hal tersebut menjadi kebiasaan dan pedoman cara berpikir, kebiasaan hati, dan kebiasaan bertindak. Pendapat filsuf Yunani Aritoteles yang mendasari pandangan Lickona menyatakan bahwa "... good character as the life of right conduct-right conduct in relation to other persons and in relation to one self" 
Karakter seseorang dikatakan baik, jika dia memiliki performance moral knowing, moral feeling, dan moral action, yang bagus . Moral knowing mencakup aspek-aspek: (1) Moral awareness, (2) Knowing moral values, (3) Perspective-taking, (4) Moral reasoning, (5) Decision-making, dan (6) Self-nowledge; Moral Feeling mencakup aspek-aspek: (1) Conscience, (2) Self-Esteem, (3) Emphaty, (4) Loving the good, (5) Self-control, dan(6) Humility; sedangkan Moral Action mencakup aspek-aspek: (1) Competence, (2) Will, dan (3) Habit. Dari sisi psikologis karakter dipandang sebagai suatu karakteristik yang komplek untuk dipahami : "Character is the complex set of psychological characteristics that enable an individual to act as a moral agent. In other words, character is multifaceted. It is psychological. It relates to moral functioning” (Berkowitz et. all., 2013).

Bila pengertian karakter dilihat dari sudut pandang yang spesifik dari suatu komunitas, maka "karakter character", mmemiliki hubungan yang kuat kaitannya dengan masalah psikologi sosial. Sebagian besar para pakar mendefinisikan karakter dalam konteks komunitas sebagai salah satu unsur kekuatan nasional (national power) dalam politik antar bangsa. Lickona (2012) memberikan definisi karakter sebagai berikut: The term "national character" is used to describe the enduring personality characteristics and unique life style found among the populations of particular national states. Artinya, istilah karakter digunakan untuk mendeskripsikan ciri-ciri kepribadian yang tetap dan gaya hidup yang khas yang ditemui pada penduduk negara bangsa tertentu. Karena terkait dengan masalah kepribadian yang merupakan bagian dan aspek kejiwaan, maka Lickona berpendapat bahwa dalam konteks perilaku, karakter bangsa dianggap sebagai istilah yang abstrak dengan aspek budaya dan termasuk dalam mekanisme psikologis yang menjadi karakteristik masyarakat tertentu.

Secara alamiah pembangunan karakter bangsa bukanlah tugas khusus misi dari Pendidikan Agama dan Pendidikan Kewarganeragaan. Berbagai mata pelajaran yang dilaksanakan di lembagan pendidikan sesungguhnya mempuyai peluang yang sama untuk digunakan sebagai sarana penguatan karakter peserta didik. Afektif merupakan bagian yang tidak dapat terpisahkan dalam setiap pembelajaran yang sangat diharapkan dapat di kembangkan dengan baik, di samping donmain lainya yang haris muncul di setiap aktivitas pembelajaran. Domain afeksi di kategorikan dalam nurturent effect, sedangkan domain utama dalam keilmuan sering di kenal dengan instructional effect, Pada domain ini setiap mata pelajaran memiliki peran sebagai pengembangan karakter peserta didik. Dari pengalaman pada pendidikan karakter di Amerika Serikat Menurut Branson, dikatakan bahwa penguatan dan pengembangkan karakter dapat dilakukan secara bersama-sama dan bertujuan untuk mengembangkan karakter secara personal dan secara umum. Karakter pribadi dapat dilihat dari bagaimana seseorang hormat kepada orang lain, tanggung jawab moral, dan dapat menghargai martabat manusia.

Dalam mengembangkan nilai-nilai karakter, Berkowitz secara konseptual memberikan strategi sebagai berikut:

"Character education has been demonstrated to be associated with academic motivation and aspirations, academic achievement, prosocial behavior, bonding to school, prosocial and democratic values, conflict-resolution skills, moral-reasoning maturity, responsibility, respect, self-efficacy, self-control, self-esteem, social skills and trust in and respect for teachers (Berkowitz, 2013).

Pendapat diatas dapat di pahami bahwa penanaman nilai karakter dapat dilakukan tidak hanya melalui pembelajaran yang mengajarkan nilai-nilai keagamaan dan moral, melainkan dapat diintegrasikan di berbagai kegiatan dan pada berbagai Mata pelajaran umum lainnya yang telah ada dalam kurikulum yang direncanakan oleh penyelenggara pendidikan. Feith \& Castles (2014) menegaskan bahwa "it is not enough for love of nation and country to be fostered by the study of civics". Menurut Feith dan Castles, pendidikan karakter tidak cukup bila hanya 
diajarkan pada pendidikan Khusus Agama, Nasionalisme dan Moralitas akan tetapi dapat dilaksanakan melalui pembelajaran yang dilaksanakan yang mengembangkan dimensi emosional, seni dan berbagai mata ajar umum lainnya.

\section{METODE PENELITIAN}

Penelitian dilaksanakan di Daerah Istimewa Yogyakarta. Populasi dalam Penelitian ini adalah Guru Akuntansi SMK Bisnis dan Manajemen di Daerah Istimewa Yogyakarta sejumlah 279 guru. Berdasarkan perhitungan sampel diambil 165 diambil dengan Proposional Purposive sampling.

Data dikumpulkan dengan angket (kuesioner), lembar observasi dan dokumentasi. Data dianalisis dengan teknik statistik deskriptif kuantitatif. Statistik deskriptif digunakan untuk menjelasjan rata-rata skor kualitas masing-masing indikator yang akan menjdi fokus dalam penelitian ini.

Analisis data penelitian dengan mengunakan analisis diskriptif kuantitatif dengan mengunakan analisis kencenderungan pada setiap komponen yuang menjadi fokus analisis, selanjutnya di jabarkan sesuai kajian teori yang telas di lakukan.

\section{HASIL DAN PEMBAHASAN}

Data penelitian yang diperoleh dari pengisian kuesioner/angket oleh guru untuk dapat mengetahui persiapan pembelajaran yang dilakukan guru dapat disajikan dalam tabel 1 sebagai berikut.

Tabel 1. Distribusi kategori persiapan pembelajaran akuntansi

\begin{tabular}{ccccc}
\hline Indikator & Interval & Frekuensi & \% & Kategori \\
\hline Persiapan & $8-9$ & 100 & 60,61 & Sangat Baik \\
Pembelajaran & $6-7$ & 55 & 33,33 & Baik \\
& $4-5$ & 5 & 3,03 & Cukup Baik \\
& $2-3$ & 5 & 3,03 & Kurang Baik \\
\hline
\end{tabular}

Tabel 1 menunjukkan kecenderungan persiapan pembelajaran pada kategori sangat baik $60,61 \%$, baik 33,33\%, cukup baik 3,03\% dan kategori kurang baik 3,03\%. Hasil analisis kecenderungan menunjukkan bahwa pembelajaran akuntansi sebagai media penanaman karakter anti korupsi ditinjau dari indikator persiapan pembelajaran termasuk dalam kategori sangat baik $(60,61 \%)$.

Data pelaksanaan pembelajaran akuntansi sebagai median penanaman karakter anti korupsi yang di peroleh dari pengisian angket oleh Guru dapat disusun kategori kecenderungan sebagai berikut.

Tabel 2. Distribusi Kategori Data Pelaksanaan Pembelajaran

\begin{tabular}{ccccc}
\hline Indikator & Interval & Frekuensi & \% & Kategori \\
\hline Pelaksanaan & $10-12$ & 92 & 55,76 & Sangat Baik \\
Pembelajaran & $8-9$ & 69 & 41,82 & Baik \\
& $6-7$ & 4 & 2,42 & Cukup Baik \\
& $3-5$ & 0 & 0 & Kurang Baik \\
\hline
\end{tabular}

Tabel 2 menunjukkan pembelajaran akuntansi ditinjau dari indikator pelaksanaan pembelajaran pada kategori sangat baik $55,76 \%$, baik 41,82 \%, cukup baik 2,42\% dan tidak ada yang memiliki kategori tidak baik. Hasil analisis kecenderungan tersebut menunjukkan 
bahwa pembelajaran akuntansi sebagai media penanaman karakter anti korupsi ditinjau dari indikator pelaksanaan pembelajaran termasuk dalam kategori sangat baik $(55,76 \%)$.

Data hasil penelitian terkait pembelajaran akuntansi ditinjau dari kegiatan penilaian pembelajaran yang dilakukan oleh guru dapat disusun kategori kecenderungan bentuk distribusi frekuensi berikut ini.

Tabel 3. Distribusi Kategori Penilaian Pembelajaran Akuntansi

\begin{tabular}{ccccc}
\hline Indikator & Interval & Frekuensi & \% & Kategori \\
\hline Penilaian & $24-18$ & 153 & 92,73 & Sangat Baik \\
Pembelajaran & $16-17$ & 10 & 6,06 & Baik \\
& $13-15$ & 2 & 1,21 & Cukup Baik \\
& $6-12$ & 0 & 0 & Kurang Baik \\
\hline
\end{tabular}

Tabel 3 menunjukkan kecenderungan pembelajaran akuntansi dari indikator penilaian pembelajaran kategori sangat baik 92,73\%, baik 6,06 \%, cukup baik 1,20 \% dan tidak ada yang memiliki kategori kurang baik. Hasil analisis kecenderungan menunjukkan bahwa pembelajaran akuntansi sebagai media penanaman karakter anti korupsi ditinjau dari indikator penilaian pembelajaran termasuk dalam kategori sangat baik $(92,73 \%)$.

Selanjutnya secara umum data penelitian menunjukknan bahwa kualitas pelaksanaan pembelajaran akuntansi sebagai media penanaman karakter anti korupsi pada 165 guru akuntansi dengan mengunakan angket/kuesioner maka dapat disusun tabel kecenderungan sebagai berikut.

Tabel 4. Kategori Kualitas Pembelajaran Akuntansi

\begin{tabular}{cccc}
\hline Interval & Frekuensi & \% & Kategori \\
\hline $44-41$ & 59 & 35,76 & Sangat Baik \\
$37-40$ & 76 & 46,06 & Baik \\
$33-36$ & 25 & 15,15 & Cukup Baik \\
$11-33$ & 5 & 3,03 & Kurang Baik \\
\hline
\end{tabular}

Tabel 4 menunjukkan bahwa secara umum kualitas pembelajaran yang dilakukan guru termasuk dalam kategori baik. Hal ini ditunjukkan dari analisis kecederungan kegiatan pembelajaran yang dilakukan guru pada kategori sangat baik 59 kegiatan/guru atau 35,76\%, kategori baik ada 76 pembelajaran/guru atau 46,06\%, kategori cukup baik 25 pembelajaran/guru atau 15,15\% dan kategori kurang baik 5 pembelajaran/guru atau 3,03\%.

Selain data dari angket/kuesioner penelitian, data kegiatan pembelajaran juga di ambil dengan lembar observasi, observasi penelitian untuk mendapatkan data kegiatan pembelajaran akuntansi sebagai penanaman karakter anti korupsi sekolah. Observasi dilakukan pada pembelajaran 165 guru di 20 Sekolah Menengah Kejuruan yang terdiri dari 6 sekolah Negeri dan 14 sekolah Swata di 5 Kabupaten/Kota di DIY. Observasi pembelajaran akuntansi yang mengitregrasikan karakter anti korupsi diperoleh lima karakter yangn muncul, yaitu (1) Kejujuran; (2) Keberanian ; (3) Kedisiplinan ; (4) Kerja Keras; (5) Mandiri. Persentase hasil pengamatan pada setiap komponen adalah seperti ditunjukkan pada Tabel 5.

Tabel 5. Pengintegrasian Nilai Anti Korupsi dalam Pembelajaran

\begin{tabular}{lclcccc}
\hline Indikator & No & Komponen Pengamatan & $\begin{array}{c}\text { Kurang } \\
\text { Baik }\end{array}$ & $\begin{array}{c}\text { Cukup } \\
\text { Baik }\end{array}$ & Baik & $\begin{array}{c}\text { Sangat } \\
\text { Baik }\end{array}$ \\
\hline \multirow{2}{*}{ Kejujuran } & 1 & $\begin{array}{l}\text { Suasana kelas saat } \\
\text { pembelajaran Akuntansi }\end{array}$ & $15,07 \%$ & $28,77 \%$ & $49,32 \%$ & $6,85 \%$ \\
\cline { 2 - 6 } & & & & & \\
\hline
\end{tabular}




\begin{tabular}{|c|c|c|c|c|c|c|}
\hline Indikator & No & Komponen Pengamatan & $\begin{array}{c}\text { Kurang } \\
\text { Baik }\end{array}$ & $\begin{array}{l}\text { Cukup } \\
\text { Baik }\end{array}$ & Baik & $\begin{array}{c}\text { Sangat } \\
\text { Baik }\end{array}$ \\
\hline & & $\begin{array}{l}\text { menunjukkan ketaatan terhadap } \\
\text { nilai-nilai Kejujuran }\end{array}$ & & & & \\
\hline & 2 & $\begin{array}{l}\text { Pembelajaran Akuntansi } \\
\text { menciptakan sikap jujur di } \\
\text { kalangan peserta didik di dalam } \\
\text { kelas }\end{array}$ & $0,00 \%$ & $36,99 \%$ & $42,47 \%$ & $20,55 \%$ \\
\hline & 3 & $\begin{array}{l}\text { Saat pembelajaran Akuntansi } \\
\text { Peserta didik dapat memutuskan } \\
\text { suatu masalah dengan jujur }\end{array}$ & $5,48 \%$ & $41,10 \%$ & $43,80 \%$ & $9,59 \%$ \\
\hline \multicolumn{3}{|c|}{ Rata-rata skor Kejujuran } & 10,27 & $35,63 \%$ & $45,21 \%$ & $12,33 \%$ \\
\hline \multirow[t]{2}{*}{ Kemandirian } & 1 & $\begin{array}{l}\text { Pembelajaran Akuntansi } \\
\text { menumbuhkan rasa } \\
\text { kemandirian antara peserta } \\
\text { didik. }\end{array}$ & $1,37 \%$ & $34,25 \%$ & $47,95 \%$ & $16,44 \%$ \\
\hline & 2 & $\begin{array}{l}\text { Tercipta kemandirian peserta } \\
\text { didik saat kegiatan } \\
\text { pembelajaran Akuntansi. }\end{array}$ & $6,84 \%$ & $26,03 \%$ & $45,21 \%$ & $21,92 \%$ \\
\hline \multicolumn{3}{|c|}{ Rata-rata skor Kemandirian } & $4,11 \%$ & $30,14 \%$ & $46,58 \%$ & $19,18 \%$ \\
\hline \multirow[t]{3}{*}{ Keberanian } & 1 & $\begin{array}{l}\text { Saat pembelajaran Akuntansi } \\
\text { terjalin komunikasi Berani } \\
\text { mengkoreksi kesalahan antar } \\
\text { peserta didik }\end{array}$ & $6,84 \%$ & $30,14 \%$ & $52,05 \%$ & $10,96 \%$ \\
\hline & 2 & $\begin{array}{l}\text { Peserta didik menunjukkan } \\
\text { sikap berani dalam berinteraksi } \\
\text { ketika berdiskusi materi } \\
\text { Akuntansi }\end{array}$ & $1,37 \%$ & $17,81 \%$ & $52,05 \%$ & $28,77 \%$ \\
\hline & Rata- & ata skor Keberanian & $4,11 \%$ & $23,97 \%$ & $52,05 \%$ & $19,86 \%$ \\
\hline \multirow[t]{2}{*}{$\begin{array}{l}\text { Kerja } \\
\text { Keras }\end{array}$} & 1 & \begin{tabular}{lrr} 
Peserta didik & \multicolumn{2}{r}{ menunjukkan } \\
sikap kerja keras dalam \\
beraktivitas di kelas & saat \\
pembelajaran Akuntansi. & \\
\end{tabular} & $10,96 \%$ & $34,25 \%$ & $35,62 \%$ & $19,18 \%$ \\
\hline & 2 & $\begin{array}{l}\text { Perilaku peserta didik saat } \\
\text { pembelajaran Akuntansi sangat } \\
\text { mengedepankan usaha yg } \\
\text { maksimal dalam bertindak. }\end{array}$ & $23,29 \%$ & $35,62 \%$ & $39,73 \%$ & $1,37 \%$ \\
\hline \multicolumn{3}{|c|}{ Rata-rata skor Kerja Keras } & $17,12 \%$ & $34.93 \%$ & $37,67 \%$ & $10,27 \%$ \\
\hline \multirow[t]{4}{*}{ Disiplin } & 3 & $\begin{array}{l}\text { Peserta didik berinteraksi } \\
\text { dengan menjunjung tinggi nilai } \\
\text { kedisiplinan saat pembelajaran } \\
\text { Akuntansi. }\end{array}$ & $24,66 \%$ & $36,99 \%$ & $30,14 \%$ & $8,219 \%$ \\
\hline & 4 & $\begin{array}{l}\text { Interaksi antar peserta didik } \\
\text { dalam pembelajaran Akuntansi } \\
\text { dilakukan dengan aturan yg } \\
\text { berlaku. }\end{array}$ & $5,48 \%$ & $35,60 \%$ & $46,60 \%$ & $12,30 \%$ \\
\hline & \multirow{2}{*}{\multicolumn{2}{|c|}{$\frac{\text { Rata-rata Skor Kedisiplinan }}{\text { Rata-rata skor Total }}$}} & $15,07 \%$ & $36,30 \%$ & $38,36 \%$ & $10,27 \%$ \\
\hline & & & $9,21 \%$ & $32,50 \%$ & $44,08 \%$ & $14,20 \%$ \\
\hline
\end{tabular}


Data hasil penelitian dari Observasi pada Tabel 5 terlihat munculnya karakter anti korupsi dalam kegiatan pembelajaran akuntansi sebagai pengembangan karakter, hal ini terlihat persentase hasil observasi menunjukkan kategori kurang baik 9,21\%, cukup baik $32,50 \%$, baik $44,08 \%$, sangat baik 14,20\%. Kecenderungan jawaban secara umum bahwa hasil pengamatan di semua komponen dominan berada pada kategori baik 44,08\%, dengan kata lain pengintegrasian karakter anti korupsi dalam pembelajaran sudah berjalan dengan baik.

Nilai kejujuran sebagai nilai anti korupsi dalam pembelajaran akuntansi menunjukkan kecenderungan kurang baik 10,27\%, cukup baik 35,63\%, baik 45,21\%, sangat baik $12,33 \%$. Hal ini berarti bahwa kegiatan pembelajaran akuntansi dilihat dari indikator interaksi antar siswa dalam pembelajaran, perilaku siswa dalam pembelajaran dan suasana pembelajaran telah mengintegrasikan nilai kejujuran dengan baik.

Nilai keberanian sebagai nilai anti korupsi dalam pembelajaran akuntansi terlihat kecenderungan kurang baik 4,11\%, cukup baik 23,97\%, baik 52,05\%, sangat baik 19,86\%. Hasil pengamatan ini menunjukkan bahwa kegiatan pembelajaran akuntansi dilihat dari indikator interaksi antar siswa dalam pembelajaran, perilaku siswa dalam pembelajaran dan suasana pembelajaran telah mengintegrasikan nilai keberanian dengan baik.

Nilai disiplin sebagai nilai anti korupsi dalam pembelajaran akuntansi menunjukkan kecenderungan kurang baik 15,07\%, cukup baik 36,30\%, baik 38,36\%, sangat baik 10,27\%. Dari hasil analisis kecenderungan terlihat bahwa kegiatan pembelajaran akuntansi dilihat dari indikator interaksi antar siswa dalam pembelajaran, perilaku siswa dalam pembelajaran dan suasana pembelajaran telah mengintegrasikan nilai kedisiplinan dengan baik.

Nilai kerja keras sebagai nilai anti korupsi dalam pembelajaran akuntansi menunjukkan kecenderungan kurang baik 17,12\%, cukup baik 34,93\%, baik 37,67\%, sangat baik 10,27\%. Analisis kecenderungan menunjukkan bahwa kegiatan pembelajaran akuntansi dilihat dari indikator interaksi antar siswa dalam pembelajaran, perilaku siswa dalam pembelajaran dan suasana pembelajaran telah mengintegrasikan nilai kerja keras dengan baik.

Nilai kemandirian sebagai nilai anti korupsi dalam pembelajaran akuntansi menunjukkan kecenderungan kurang baik $4,11 \%$, cukup baik $30,14 \%$, baik $46,58 \%$, sangat baik 19,18\%. Hal ini dapat disimpulkan bahwa kegiatan pembelajaran akuntansi dilihat dari indikator interaksi antar siswa dalam pembelajaran, perilaku siswa dalam pembelajaran dan suasana pembelajaran telah mengintegrasikan nilai kemandirian dengan baik.

Penelitian yang dilakukan Muhlisin (2018) selaras dengan penelitian ini yang menyatakan bahwa Penerapan pembelajaran anti korupsi, pembiasaan anti korupsi maupun program pengembangan diri penunjang pendidikan karakter tidak akan berjalan secara maksimal apabila tidak ada proses pemberian keteladanan oleh kepala sekolah, para guru maupun tenaga kependidikan. Penelitian ini juga selaras dengan penelitian sebelumnya yang dilakukan Masrukhi (2001) menyatakan bahwa dengan adanya strategi yang baik dalam pembelajaran Akuntansi akan mempegaruhi keberhasilan Pembelajaran dalam mengintegrasikan nilai-nilai Anti Korupsi. Hasil penelitian menegaskan bahwa pembelajaran anti korupsi lebih tepat dengan mengunakan strategi kegiatan pembiasaan, ini menegaskan pentingnya strategi pembelajaran yang tepat untuk pengintegrasian nilai Anti korupsi dalam Pembelajaran. Penelitian ini juga mengemukanan adanya pendidikan sikap antikorupsi di sekolah membentuk sikap jujur, tanggung jawab, berani, adil terbuka, kerja keras, dan disiplin. Hal ini memantapkan hasil penelitian bahwa nilai-nilai anti korupsi dapat terbentuk dari kultur sekolah yang telah mengedepankan nilai jujur, tanggung jawab, berani adil, kerja keras dan disiplin. 


\section{Implikasi Karakter Anti Korupsi dalam Pembelajaran Akuntansi}

Pembelajaran yang dilakukan guru dan siswa merupakan kegiatan belajar yang memberikan arti penting bagi peserta didik, hal ini agar peserta didik menyadari bahwa mereka merupakan bagian utama atau dalam arti luas sebagai sumberdaya utama yang turut serta menentukan masa depan bangsa dan negara ini ke depan. Kegiatan ini merupakan upaya yang dilakukan sebagai kegiatan preventif pada aktivitas yang mengarah pada korupsi.

Pemahaman yang dimiliki tentang anti korupsi akan berdampak pada pembentukan sikap anti korupsi pada peserta didik. Untuk itu kegiatan pembelajaran diharapkan benar-benar memastikan bahwa siswa memahami akan ciri-ciri, penyebab dan hal yang ditimbulkan dari korupsi. Guru diharapkan menambah berbagai pengalaman yang bermakna dengan berbagai aktivitas yang menarik agar siswa benar-benar memahami dan mengerti makna yang diharapkan. Salah satu faktor penting dari pembelajaran anti korupsi adalah bagaimana siswa dapat menentukan pilihan dan satu pertimbangan pelaksanaan nilai-nilai moral terkait tindakan korupsi, hal ini dapat ditentukan oleh aktivitas yang membangun kognisi yang dimiliki. Berdasarkan pengelompokan yang dilakukan Kohlberg siswa pada usia pertengahan memiliki kemampuan untuk memahami hal-hal yang terjadi di sekitarnya, karena itu mereka memiliki kemampuan untuk membuat pertimbangan yang baik terhadap nilai moral yang diharapkan untuk menentukan apakah suatu perbuatan tersebut dapat dikategorikan sesuai atau menyimpang dari nilai-nilai kepribadian dalam masyarakat. Melalui berbagai pembahasan tentang nilai moral dari tindakan yang mengarah pada tindakan korupsi, peserta didik dapat memiliki pengetahuan lebih luas akan pemilihan tindakan-tindakan yang sesuai dengan nilai moralitas yang tidak mengarah pada tindakan korupsi, hal ini akan meningkatkan pemahaman tentang moralitas mereka, dan lebih jauh lagi akan memberikan tambahan kemampuan siswa untuk membuat pertimbangan moral mengenai berbagai kasus yang terjadi di sekitarnya. Dengan belajar dan melaksanakan secara langsung terkait dengan berbagai kegiatan yang mengarah pada korupsi, siswa bisa memposisikan dirinya jika berada pada bagian yang rawam pada tindakan korup dan bagaimana langkah - langkah yang diambil siswa untuk mencegahnya. Aktivitas seperti ini apabila dapat dielaborasi dengan bagus akan memberikan arti penting dan pemahaman kepada peserta didik bahwa korupsi merupakan aktivitas yang tidak sesuai dengan nilai-nilai moralitas yang kurang baik dan harus di cegah. Selanjutnya kemampuan pendidik dalam mengelola berbagai komponen pembelajaran akan menentukan bagaimana aktivitas pembelajaran anti korupsi dapat mencapai tujuan dengan baik. Tujuan lainnya terhadap aktivitas belajar adalah dapat menjadi ruang untuk melakukan berbagai aktifitas sebagai praktik bagi siswa untuk melatihkan dan membiasakan penerapan nilai-nilai dasar anti korupsi.

\section{KESIMPULAN}

Dari data hasil penelitian dapat disimpulkan (1) Persiapan Pembelajaran Akuntansi pada kategori sangat baik sebagai media penanaman karakter anti korupsi; (2) Pelaksanaan Pembelajaran Akuntansi pada kategori sangat baik sebagai media penanaman karakter anti korupsi; (3) Penilaian Pembelajaran Akuntansi pada kategori sangat baik sebagai media penanaman karakter anti korupsi; (4) Kualitas Pembelajaran Akuntansi pada kategori baik sebagai media penanaman karakter anti korupsi ; (5) Nilai-nilai karakter anti korupsi yanag muncul dalam pembelajaran : Kejujuran pada kategori Baik, kemandirian pada kategori baik, keberania pada kategori baik, Kerjakeras pada kategori baik dan Disiplin pada kategori Baik.

Pendidikan anti korupsi merupakan program yang memiliki misi utama untuk mengembangkan dan menambah pemahaman siswa akan resiko yang ditimbulkan dari tindakan korupsi. Salah satu tujuan penanaman nilai-nilai anti korupsi adalah memberikan gambaran berbagai aktivitas yang berpotensi timbulnya korupsi yang meliputi ciri-ciri aktivitas 
yang mengarah korupsi, hal-hal yang memicu dan akibatnya, menumbuhkan penilaian tidak setuju terhadap aktivitas korupsi, serta menunjukan kegiatan yang dilakukan untuk menghindari tindakan korupsi dan aktif dalam mengimplementasikan nilai-nilai anti korupsi dan menentang korupsi pada generasi muda.

Penyampaian Materi-materi Akuntansi hendaknnya dilakukan latihan langsung dan bersifat individual. Hal ini dimaksudkan untuk membiasakan cara kerja dan beifikir mandiri. Sikap hidup yang produktif dan mandiri dibentuk dengan penerapan metode latihan untuk setiap materi yang diberikan. Pendidikan anti korupsi akan memiliki arti penting bagi siswa dengan memposisikan Akuntansi pada aktivitas preventif. Siswa akan memiliki pemahaman bahwa pendidikan anti korupsi tidak hanya urusan politik saja, melainkan masalah kita semua sebab mereka adalah orang-orang yang berpotensi untuk melakukan korupsi jika melaksanakan pemncatatan/pembukuan tidak sebagai mana mestinya.

\section{DAFTAR PUSTAKA}

Adnan, Akhyar (2016). Bagi hasil" dalam Bank Islam: Beban (biaya) atau bukan? . UII Press. Yogyakarta

Al. Haryono Jusup. (2011). Dasar-Dasar Akuntansi jilid 2. Edisi Tujuh. STIE Press, Yogyakarta.

Branson, Margaret Stimmann, (1998), The role of civic education: aforthcoming education policy task force position paper from the communitarian network, Calabasas: cce.

Berkowitz, A., (2013), Patofisiologi Klinik Disertai Contoh Kasus Klinik, Diterjemahkan oleh Andry Hartono, Halaman 108, Tangerang, Binarupa Aksara

Catherine \& Petter Lehmann. (2013). Tools for Strengths-Based Assessment and Evaluation. Springer publishing Company. New York.

Cronbach, L. J., \& Shavelson, R. J. (2004). Educational and Psychological Measurement: New York: Harcourt Brace Jovanovich, Inc.

Dharma, Budi. (2013). Korupsi dan Budaya. dalam Kompas, 25/10/2013

Dee Fink, L. (2002). Active learning. Kertas kerja. Tidak diterbitkan

Feith, Herbert and Castles, Lance. (2014). Indonesian Political Thinking (1945-

1965). Ithaca, New York: Cornell University Press.

Warren dkk. (2015). Pengantar Akuntansi, Edisi 21. Jakarta: Salemba Empat.

Ghofur, Syaiful Amin (2009) Merancang kurikulum pendidikan antikorupsi. Jurnal Pendidikan Islam. vol. 01, no.01, ISSN 2085-3033

Kauchack, Donald P \& Eggen, Paul D. (2008). Learning and Teaching Research BasedMethods.Pearson Education : Boston

Kieso, Donald E. Jerry J.Weygandt, Paul D. Kimmel. (2014). Accounting PrinciplesPengantar Akuntansi Edisi 7Jilid 1. Jakarta: Salemba Empat 
Kozulin, Alex (Ed). (2007) Vygotsky"s educational theory in cultural contect. Cambridge University Press : USA

Lickona, Thomas. (2012). My Thoughts about national character. Ithaca and London: Cornell University Press (2014). Character Matters. Touchstone : New York

Nafarin. (2015). Penganggaran Perusahaan jilid 3. Jakarta: Salemba Empat.

Masrukhi. (2001). Pemanfaatan media dalam pembelajaran PPKn di SMU di Kota Semarang, hasil penelitian, tidak diterbitkan. Unnes : Lembaga Penelitian Unnes

Modern Didactic Center. (2006). Anti Corruption Education At School. Garnelish Publishing : Vilnius. Lithuania

Muhlisin. (2018). Pembentukan karakter Melaluifull Day Schoolpada Peserta Didikdimadrasah Ibtidaiyahnurul Ummah kotagede Yogyakarta.Skripsi. Yogyakarta

Republik Indonesia. (1999). Undang-Undang No.31 Tahun 1999 tentang Pemberantasan Tindak Pidana Korupsi.

Republik Indonesia. (2001). Undang-Undang No.20 Tahun 2001 tentang Pemberantasan Tindak Pidana Korupsi.

Warsono, sony. (2013).Akuntansi Pengantar 1. Yogyakarta: Penerbit BukuAkuntansi

Worthen, B. R., Sanders, J. R., \& Fitzpatrick, J. L. (2012). Program Evaluation: Alternative Approaches and Practical Guidelines (4th Edition).Addison Wesley 